\title{
Isolation of two distinct prion strains from a scrapie-affected sheep
}

\author{
Kentaro Masujin · Yujing Shu • Hiroyuki Okada • \\ Yuichi Matsuura Yoshifumi Iwamaru • Morikazu Imamura • \\ Shirou Mohri $\cdot$ Takashi Yokoyama
}

Received: 27 July 2009/ Accepted: 29 September 2009/Published online: 30 October 2009

(C) The Author(s) 2009. This article is published with open access at Springerlink.com

\begin{abstract}
We performed a transmission study using mice to clarify the characteristics of the most recent case of scrapie in Japan. The mice that were inoculated with the brain homogenate from a scrapie-affected sheep developed progressive neurological disease, and one of the scrapieaffected mice showed unique clinical signs during primary transmission. This mouse developed obesity, polydipsia, and polyuria. In contrast, the other affected mice exhibited weight loss and hypokinesia. In subsequent passages, the mice showed distinct characteristic scrapie phenotypes. This finding may prove that different prion strains coexist in a naturally affected sheep with scrapie.
\end{abstract}

$\begin{array}{ll}\text { Abbreviations } \\ \mathrm{PrP}^{\mathrm{Sc}} \quad \text { Abnormal prion protein } \\ \mathrm{CNS} & \text { Central nervous system } \\ \mathrm{Ka} / \mathrm{O} & \text { Kanagawa/scrapie obesity-type prion } \\ \mathrm{Ka} / \mathrm{W} & \text { Kanagawa/scrapie weight-loss-type prion } \\ \mathrm{mAb} & \text { Monoclonal antibody } \\ \mathrm{PrP} & \text { Prion protein } \\ \mathrm{PrPcore} & \text { Proteinase-K-digested } \mathrm{PrP}^{\mathrm{Sc}} \\ \text { sCJD } & \text { Sporadic Creutzfeldt-Jacob disease } \\ \mathrm{TSE} & \text { Transmissible spongiform encephalopathy } \\ \mathrm{WB} & \text { Western blotting }\end{array}$

K. Masujin and Y. Shu contributed equally to this work.

K. Masujin · Y. Shu · H. Okada · Y. Matsuura · Y. Iwamaru M. Imamura · S. Mohri · T. Yokoyama $(\bowtie)$

Prion Disease Research Center, National Institute of Animal Health, 3-1-5 Kannondai, Tsukuba, Ibaraki 305-0856, Japan e-mail: tyoko@affrc.go.jp
Scrapie is a transmissible spongiform encephalopathy (TSE) that affects sheep and goats. It is characterized by spongiform changes in the central nervous system (CNS) and accumulation of an abnormal prion protein $\left(\operatorname{PrP}^{\mathrm{Sc}}\right)$ in the CNS and lymphoid tissues; $\operatorname{PrP}^{\mathrm{Sc}}$ is the major component of prions [1]. Thus far, multiple strains of scrapie prions have been identified [2-6]. These strains can be distinguished on the basis of the incubation period, the lesion profile, and the pattern of the $\mathrm{PrP}^{\mathrm{Sc}}$ accumulation in the transmission studies with mice. The characteristic phenotypes of these prion strains are conserved during serial passage within a single host [2]. However, the mechanism of emergence of prion strains is still unknown.

A 60-month-old Suffolk ewe developed ananastasia and eventually died in Kanagawa prefecture, Japan, and it was diagnosed as scrapie (Ka/scrapie). To clarify the biological properties of prions in this most recent case of scrapie in Japan, we examined the transmissibility of scrapie prions in wild-type ICR mice ( $\operatorname{PrP}$ allotype $\operatorname{PrP}^{\mathrm{A} / \mathrm{A}}$; $\operatorname{PrP}^{\mathrm{A}}$ encodes PrP with leucine at codon 108 and threonine at codon 189; Japan SLC, Inc., Japan) by using previously described methods [7]. All of the mice that were inoculated with the brain homogenate of scrapie-affected sheep developed progressive neurological diseases; one of the diseaseaffected mice exhibited unique clinical signs during primary transmission (Table 1). After an incubation period of 469 days, this mouse developed obesity, polydipsia, and polyuria followed by slowness of movement; the prion responsible for these symptoms is designated as the $\mathrm{Ka} /$ scrapie obesity-type $(\mathrm{Ka} / \mathrm{O})$ prion. In contrast, after an incubation period of $457 \pm 21.1$ days, the other diseaseaffected mice (15) exhibited weight loss, hypokinesia, and uncoordinated hind-limb movements; the prion responsible for these symptoms was designated as the $\mathrm{Ka} / \mathrm{scrapie}$ weight-loss-type $(\mathrm{Ka} / \mathrm{W})$ prion. To further investigate the 
Table 1 Transmission of $\mathrm{Ka} /$ scrapie in wild-type ICR mice

\begin{tabular}{|c|c|c|c|c|c|}
\hline First p & sssage $\left(16 / 16^{a}\right)$ & & Second passage & & Third passage \\
\hline $15 / 16^{\mathrm{b}}$ & $457 \pm 21.1^{\mathrm{c}}$ & $\rightarrow$ & $5 / 5 \quad 255.8 \pm 28.8$ & $\rightarrow$ & $10 / 10 \quad 151.5 \pm 5.6$ \\
\hline $1 / 16^{\mathrm{d}}$ & 469 & $\rightarrow$ & $5 / 5 \quad 287.0 \pm 6.5$ & $\rightarrow$ & $10 / 10 \quad 272.3 \pm 29.0$ \\
\hline
\end{tabular}

${ }^{a}$ Number of infected mice/number of inoculated mice

${ }^{\mathrm{b}}$ Mice exhibiting weight loss and hind-limb ataxia. All of these mice showed the same clinical signs and same neuropathological phenotype. The brain homogenate of 1 of the 15 mice was used for the second passage (incubation period, 463 days)

c Average \pm standard deviation (days)

${ }^{d}$ A single mouse exhibiting polydipsia, polyuria, and obesity

properties of these prions, brain homogenates from the $\mathrm{Ka} / \mathrm{O}$ - and $\mathrm{Ka} / \mathrm{W}$-affected mice were inoculated into wildtype mice, and these mice were subjected to neuropathological and biochemical examinations. The mice that were inoculated with the brain homogenate of the $\mathrm{Ka} / \mathrm{O}$-affected mouse developed obesity, polydipsia, and polyuria after an incubation period of $287.0 \pm 6.5$ days. Conversely, those inoculated with the brain homogenate of the $\mathrm{Ka} / \mathrm{W}$-affected mice exhibited weight loss and hind-limb ataxia after an incubation period of $255.8 \pm 28.2$ days. Moreover, mice in the subsequent $\mathrm{Ka} / \mathrm{O}$ and $\mathrm{Ka} / \mathrm{W}$ passage lines showed different clinical signs, and the incubation periods of the third passage lines in the $\mathrm{Ka} / \mathrm{O}$ - and $\mathrm{Ka} / \mathrm{W}$-affected mice were $272.3 \pm 29.0$ and $151 \pm 5.6$ days, respectively. The body weights of the $\mathrm{Ka} / \mathrm{O}$ - and $\mathrm{Ka} / \mathrm{W}$-affected mice at the third passage are shown in Table 2.

Neuropathological examinations of these mice were performed by using previously described methods [7]. Spongiform changes were detected throughout the brains of both the $\mathrm{Ka} / \mathrm{W}$ - and $\mathrm{Ka} / \mathrm{O}$-affected mice. The degree of vacuolation in the brains of the $\mathrm{Ka} / \mathrm{W}$-affected mice was more severe than that in the $\mathrm{Ka} / \mathrm{O}$-affected mice (Fig. 1a-c). Immunohistochemical analyses were performed by using previously described methods [7, 8]. The $\operatorname{PrP}^{\mathrm{Sc}}$ types and their distributions in the $\mathrm{Ka} / \mathrm{O}$ - and $\mathrm{Ka} / \mathrm{W}$-affected mice were different (Fig. 1d-g). Punctate and fine granular $\operatorname{PrP}^{\mathrm{Sc}}$ were predominantly and uniformly distributed throughout the brains of the Ka/W-affected mice (Fig. 1d, f). In contrast, in the $\mathrm{Ka} / \mathrm{O}$-affected mice, coarse granular $\mathrm{PrP}^{\mathrm{Sc}}$ was predominantly distributed in the thalamus, the brain stem, and the cerebral cortex (Fig. 1e, g), while PrP plaques were observed in the corpus callosum, the thalamus, and the cerebral cortex (inset of Fig. 1e).

In recent studies, prion strains have been distinguished on the basis of the biochemical properties of the $\mathrm{PrP}^{\mathrm{Sc}}$, such as the glycoform ratio and the molecular mass of proteinase-K-digested $\mathrm{PrP}^{\mathrm{Sc}}$ (PrPcore) [9-13]. We characterized the PrPcore molecules that had been extracted from the brains of the $\mathrm{Ka} / \mathrm{O}$ - and $\mathrm{Ka} / \mathrm{W}$-affected mice by using a previously described method [14]. Western blotting (WB) analysis revealed that the PrPcore obtained from the $\mathrm{Ka} / \mathrm{O}$ and $\mathrm{Ka} / \mathrm{W}$-affected mice had similar glycoform patterns and molecular mass (Fig. 2). These results indicate that two strains of prions with distinct properties were isolated from a single source, i.e., the brain of the scrapie-affected sheep.

Different types of $\mathrm{PrP}^{\mathrm{Sc}}$ (types 1 and 2) were reported to co-exist in a case of sporadic Creutzfeldt-Jacob disease (sCJD) [15]. Scrapie in sheep is also proposed to be caused by mixed populations of different prion strains $[16,17]$. In the present study, different prion strains were isolated from the brain of a scrapie-affected sheep during the primary transmission studies. In the previously reported CJD case, the PrPcore sizes of the two strains were different. In contrast, in the case reported in this study, although their PrPcore sizes were not different, the prions of the two strains showed distinct biological characteristics. In addition, this result showed that a transmission study using experimental animals is a useful approach for the isolation and characterization of prion strains. New TSE strains are believed to emerge due to mutations caused by differences in the primary PrP sequences of the host and the inoculum [17]. We observed that 3 out of 31 mice showed the characteristic clinical signs of the $\mathrm{Ka} / \mathrm{O}$ strain in repeat trials of $\mathrm{Ka} /$ scrapie transmission (data not shown). This data indicates that the $\mathrm{Ka} / \mathrm{O}$ strain shows a constant occurrence rate of 6-9\%. Therefore, our findings may indicate that mixed prion populations exist in a

Table 2 Body weights of the $\mathrm{Ka} / \mathrm{W}$ - and $\mathrm{Ka} / \mathrm{O}$-affected wild-type ICR mice

\begin{tabular}{|c|c|c|c|c|c|c|c|}
\hline \multirow[t]{2}{*}{ Inoculum $^{a}$} & \multirow[t]{2}{*}{ Mouse numbers } & \multicolumn{6}{|c|}{ Weeks post-inoculation } \\
\hline & & 0 & 12 & 20 & 28 & 32 & 36 \\
\hline $\mathrm{Ka} / \mathrm{W}$ & 6 & $12.3 \pm 1.0^{\mathrm{b}}$ & $39.5 \pm 7.8$ & $36.2 \pm 6.9^{*}$ & & & \\
\hline $\mathrm{Ka} / \mathrm{O}$ & 6 & $12.5 \pm 0.9$ & $44.1 \pm 3.8$ & $56.8 \pm 5.5^{*}$ & $68.8 \pm 3.7 * *$ & $68.6 \pm 7.5^{*}$ & $61.4 \pm 9.4$ \\
\hline Control & 6 & $12.6 \pm 0.7$ & $40.1 \pm 6.4$ & $47.5 \pm 9.0$ & $49.0 \pm 9.0$ & $46.2 \pm 6.9$ & $47.8 \pm 8.9$ \\
\hline
\end{tabular}

The asterisks indicate statistically significant differences between the scrapie-affected mice and the age-matched control mice (Student's $t$ test: $* p<0.05 ; * * p<0.001)$

${ }^{\text {a }} \mathrm{Ka} / \mathrm{scrapie}$ weight-loss-type prion $(\mathrm{Ka} / \mathrm{W})$ - and $\mathrm{Ka} / \mathrm{scrapie}$ obesity-type prion $(\mathrm{Ka} / \mathrm{O})$-affected ICR mice at third passage were analyzed

b Average \pm standard deviation (gram) 
(a)
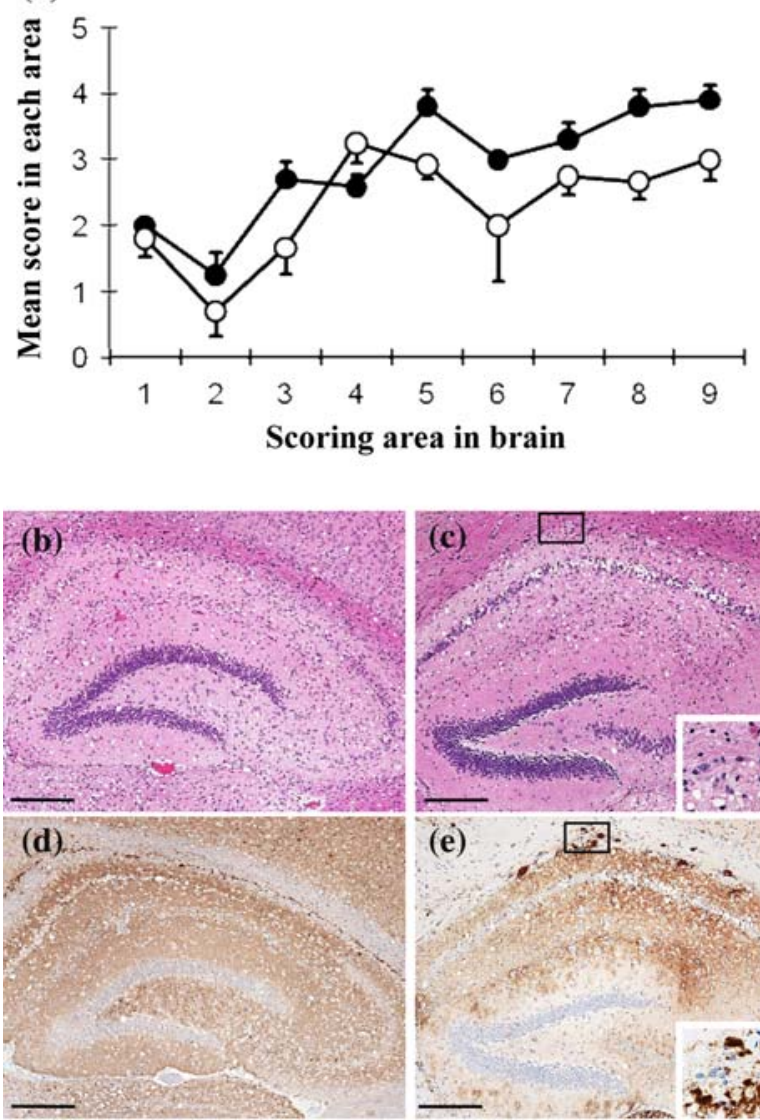

(f)

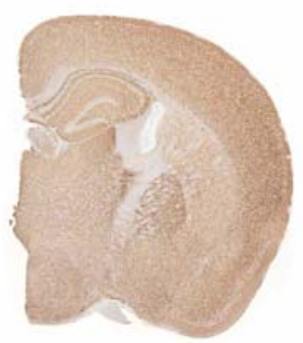

$\mathrm{Ka} / \mathbf{W}$
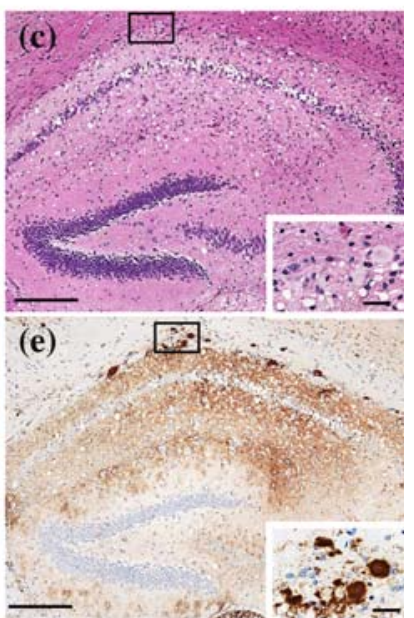

(g)



$\mathrm{Ka} / \mathbf{O}$

Fig. 1 Neuropathological analysis of the Ka/scrapie weight-loss-type prion $(\mathrm{Ka} / \mathrm{W})$ - and $\mathrm{Ka} / \mathrm{scrapie}$ obesity-type prion $(\mathrm{Ka} / \mathrm{O})$-affected mice. a Lesion profile of the affected mice. The vacuolation in the following brain regions was scored on a scale of $0-5$ (mean values): 1 dorsal medulla, 2 cerebellar cortex, 3 superior cortex, 4 hypothalamus, 5 thalamus, 6 hippocampus, 7 septal nuclei of the paraterminal body, 8 cerebral cortex at the levels of the hypothalamus and the thalamus, and 9 cerebral cortex at the level of the septal nuclei of the paraterminal body [18]. Filled circle $\mathrm{Ka} / \mathrm{W}(n=5)$, open circle $\mathrm{Ka} / \mathrm{O}(n=5)$. A section of the hippocampus of the affected mice was stained with hematoxylin and eosin (b, c), and immunostaining was performed by using the monoclonal antibody (mAb) SAF84 $(\mathbf{d}-\mathbf{g})$. The coronal sections at the level of the hippocampus are shown $(\mathbf{f}, \mathbf{g})$. The insets in the lower right corners $(\mathbf{c}, \mathbf{e})$ are enlarged images of the small boxes in the corresponding panels. The bar represents $200 \mu \mathrm{m}$ in $\mathbf{b}-\mathbf{d}$ and $25 \mu \mathrm{m}$ in the insets of $\mathbf{c}$ and $\mathbf{e}$

scrapie-affected sheep and that one of these strains becomes dominant during prion propagation in mice. Our results suggested that the $\mathrm{Ka} / \mathrm{W}$ strain was the dominant

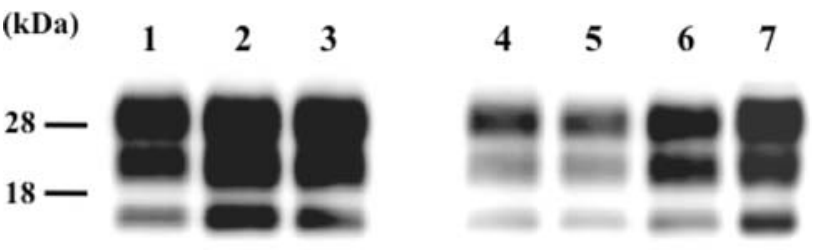

Fig. 2 Western blotting (WB) analysis for detecting proteinase-Kdigested prion protein (PrPcore) in the brains of $\mathrm{Ka} /$ scrapie weight-losstype prion $(\mathrm{Ka} / \mathrm{W})$ - and $\mathrm{Ka} /$ scrapie obesity-type prion $(\mathrm{Ka} / \mathrm{O})$-affected mice. Lanes 1-3 Ka/W-affected mice, lanes 4-6 Ka/O-affected mice, lane $7 \mathrm{Ka} /$ scrapie. Lanes 1 and 4 : mice in the first passage; lanes 2 and 5 : mice in the second passage; and lanes 3 and 6 : mice in the third passage. The equivalent of $0.25 \mu \mathrm{g}$ of brain tissue was loaded into each lane. PrPcore was detected using the monoclonal antibody (mAb) T2 [19]. The molecular markers are shown on the left $(\mathrm{kDa})$

strain in the brain of $\mathrm{Ka} / \mathrm{scrapie}$-affected sheep, while the $\mathrm{Ka} / \mathrm{O}$ strain seemed to be the less dominant strain, which may have been inefficiently selected during interspecies transmission.

In this study, we examined the biological characteristics of prions in the most recent case of scrapie in Japan. On the basis of our results, we conclude that multiple prion strains coexist in a scrapie-affected sheep. To elucidate the molecular epidemiology of prion diseases, further studies should be conducted to clarify the mechanism underlying the emergence of new prion strains.

Acknowledgments All animal experiments were reviewed by the Committee of the Ethics on Animal Experiment of the National Institute of Animal Health. We are thankful to Naoko Tabeta and Mutsumi Sakurai for their technical assistance. This study was supported by a grant-in-aid from the BSE and other Prion Disease Control Project of the Ministry of Agriculture, Forestry, and Fisheries, Japan.

Open Access This article is distributed under the terms of the Creative Commons Attribution Noncommercial License which permits any noncommercial use, distribution, and reproduction in any medium, provided the original author(s) and source are credited.

\section{References}

1. Prusiner SB (1991) Molecular biology of prion diseases. Science 252:1515-1522

2. Kimberlin RH, Walker CA, Fraser H (1989) The genomic identity of different strains of mouse scrapie is expressed in hamsters and preserved on reisolation in mice. J Gen Virol 70:2017-2025

3. Bruce ME (1993) Scrapie strain variation and mutation. Br Med Bull 49:822-838

4. Shinagawa M, Takahashi K, Sasaki S, Doi S, Goto H, Sato G (1985) Characterization of scrapie agent isolated from sheep in Japan. Microbiol Immunol 29:543-551

5. Horiuchi M, Nemoto T, Ishiguro N, Furuoka H, Mohri S, Shinagawa M (2002) Biological and biochemical characterization of sheep scrapie in Japan. J Clin Microbiol 40:3421-3426 
6. Hirogari Y, Kubo M, Kimura KM, Haritani M, Yokoyama T (2003) Two different scrapie prions isolated in Japanese sheep flocks. Microbiol Immunol 47:871-876

7. Masujin K, Shu Y, Yamakawa Y, Hagiwara K, Sata T, Matsuura Y, Iwamaru Y, Imamura M, Okada H, Mohri S, Yokoyama T (2008) Biological and biochemical characterization of L-typelike bovine spongiform encephalopathy (BSE) detected in Japanese black beef cattle. Prion 2:123-128

8. Furuoka H, Yabuzoe A, Horiuchi M, Tagawa Y, Yokoyama T, Yamakawa Y, Shinagawa M, Sata T (2007) Species-specificity of a panel of prion protein antibodies for the immunohistochemical study of animal and human prion diseases. J Comp Pathol 136:7-9

9. Bessen RA, Marsh RF (1992) Biochemical and physical properties of the prion protein from two strains of the transmissible mink encephalopathy agent. J Virol 66:2096-2101

10. Collinge J, Sidle KC, Meads J, Ironside J, Hill AF (1996) Molecular analysis of prion strain variation and the aetiology of 'new variant' CJD. Nature 383:685-690

11. Parchi P, Capellari S, Chen SG, Petersen RB, Gambetti P, Kopp N, Brown P, Kitamoto T, Tateishi J, Giese A, Kretzschmar H (1997) Typing prion isoforms. Nature 386:232-234

12. Somerville RA, Chong A, Mulqueen OU, Birkett CR, Wood SC, Hope J (1997) Biochemical typing of scrapie strains. Nature 386:564
13. Kuczius T, Groschup MH (1999) Differences in proteinase $\mathrm{K}$ resistance and neuronal deposition of abnormal prion proteins characterize bovine spongiform encephalopathy (BSE) and scrapie strains. Mol Med 5:406-418

14. Yokoyama T, Kimura KM, Ushiki Y, Yamada S, Morooka A, Nakashiba T, Sassa T, Itohara S (2001) In vivo conversion of cellular prion protein to pathogenic isoforms, as monitored by conformation-specific antibodies. J Biol Chem 276:11265-11271

15. Puoti G, Giaccone G, Rossi G, Canciani B, Bugiani O, Tagliavini F (1999) Sporadic Creutzfeldt-Jacob disease: co-occurrence of different types of $\mathrm{PrP}^{\mathrm{Sc}}$ in the same brain. Neurology 53:21732176

16. Kimberlin RH, Walker CA (1978) Evidence that the transmission of one source of scrapie agent to hamsters involves separation of agent strains from a mixture. J Gen Virol 39:487-496

17. Collinge J, Clarke AR (2007) A general model of prion strains and their pathogenicity. Science 318:930-936

18. Fraser H, Dickinson AG (1968) The sequential development of the brain lesion of scrapie in three strains of mice. J Comp Pathol 78:301-311

19. Hayashi HK, Yokoyama T, Takata M, Iwamaru Y, Imamura M, Ushiki YK, Shinagawa M (2005) The N-terminal cleavage site of $\mathrm{PrP}^{\mathrm{Sc}}$ from BSE differs from that of $\mathrm{PrP}^{\mathrm{Sc}}$ from scrapie. Biochem Biophys Res Commun 328:1024-1027 